\title{
STRATEGIC MANAGEMENT MODEL TO PROMOTE COMPETITIVENESS IN TOURISM COMPANIES IN CAÑETE
}

\begin{abstract}
Alex Abelardo Pacheco Pumaleque
Universidad Nacional de Cañete - UNDG, Lima, (Perú). E-mail: apacheco@undc.edu.pe ORCID: https://orcid.org/0000-0001-9721-0730

Nestor Guba Garbajal

Universidad Nacional de Cañete - UNDG, Lima, (Perú). E-mail:ncuba@undc.edu.pe ORCID: https://orcid.org/0000-0002-7767-3751

Miriam Viviana Ñañez Silva

Universidad Nacional de Cañete - UNDC, Lima, (Perú). E-mail: mnanez@undc.edu.pe ORCID: https://orcid.org/0000-0001-8929-2916
\end{abstract}

Liz Beni Pacheco Pumaleque

Universidad Nacional Mayor de San Marcos - UNMSM, Lima, (Perú). E-mail: liz.pacheco@unmsm.edu.pe ORCID: https://orcid.org/0000-0002-4323-1293

Recepción: 07/10/2020 Aceptación: 04/12/2020 Publicación: 08/01/2021

Gitación sugerida Suggested citation

Pacheco, A. A., Cuba, N., Nañez, M. V., y Pacheco, L. B. (2021). Strategic management model to promote competitiveness in tourism companies in Cañete. 3C Empresa. Investigación y pensamiento crítico. Edición Especial Tourism and University: Backbone of Peruvian Economy, 17-31. https://doi. org/10.17993/3cemp.2021.specialissue1.17-31 


\section{ABSTRACT}

Today's tourism environment is increasingly competitive, so strategic management is a fundamental process that every company must implement to evaluate the business, define goals, develop strategies and identify resources for their realization. Due to the pandemic, the tourism sector is facing new challenges to stay in the market. Therefore, we propose a strategic management model to improve the competitiveness of tourism companies. We used the survey technique to collect information regarding the variables strategic management and competitiveness with its dimensions change management, staff training, service quality, differentiation and technology management, which was addressed to 20 managers in the sector resulting in a Cronbach's alpha coefficient of 0.823 . The results show that $60 \%$ of managers indicate that the change management capacity of their companies is regular. The results show that $60 \%$ of managers indicate that the change management capacity of their companies is regular. $55 \%$ indicate that the training of tourism personnel is regular, $60 \%$ express that the differentiation strategy of their company is bad. These results reflect that Cañete tourism companies must implement strategic management for the development of productive capacities for their organizations, improving competitiveness through new products, services and processes.

\section{KEYWORDS}

Strategic Management, Competitiveness, Tourism companies, Model. 


\section{INTRODUCTION}

Strategic management is an essential tool for the analysis and assessment of the company since it allows managers to develop, formulate and evaluate strategies for the optimization of the resources of each area in the company (Eliécer \& Herrera, 2011). One must have the ability to interpret information, make decisions to remain in a competitive market and lead the company on the path to success benefiting partners, staff and customers. To make a company grow and succeed requires a long-term vision with goals and objectives that can be achieved over time. Strategic management directs the actions of the company towards success by promoting the necessary changes and overcoming obstacles reflecting the growth of competitiveness and productivity in the company (Stratec, 2019). The tourism sector is affected by constant changes and lack of knowledge about what the future of tourism destinations holds. In order to achieve good management, the competitive position of tourism destinations must be guaranteed in relation to their management and planning (Quintana, 2019). For tourism management, statistical information and economic reports reduce uncertainty and help in decision-making for the proper management of tourism destinations.

Competition among companies that promote tourist attractions in the province of Cañete is constantly increasing, which requires strategic management that includes change management, personnel training, service quality and differentiation, and technological innovation management (Baharudin et al., 2020; Wetli, 2018; Holis et al., 2018; Angel et al., 2016; Tavera, 2017). Without strategic management, opportunities to achieve goals and expand the company are lost, resources are inadequately managed, and processes are not efficient. In this context, there are many challenges for companies in the tourism sector that are trying to achieve better results in their performance and from this perspective this research seeks to propose a strategic management model to promote competitiveness in tourism companies in Cañete, contributing directly as a tool that allows increasing productivity, improving service quality, differentiation and undertaking change management obtaining new products, services and processes. 


\section{THEORETICAL BASES}

The increase in competition between organizations led to the origin of strategic management based on long-term planning, due to the relationship between technological innovation activity and business management that is increasing every day (Fanyoujun, 2019). Strategic management is a continuous process that reviews strategies and develops them in a forwardlooking manner, allowing organizations to achieve their objectives, considering their limitations and capacities in the operating environment. Companies use tools to strengthen their internal capacity, improve their competitive performance, meet the requirements of the environment and reflect on the medium and long term future (Gimbert, 2010). In addition, it serves as a support for decision making, and it manages to coordinate and reach consensus on organizational decisions. For organizations, traditional strategic management acquires new characteristics due to the implementation of foresight mechanisms such as change management (Merzlikina \& Kozhanova, 2020). Foresight focuses on the importance of strategic vision, which serves as a fundamental part of the vision of the future of the company.

The importance of strategic management in tourism focuses on devoting more attention to the analysis of the environment by formulating strategies that are directly related to the environment. Today's tourism environment is increasingly complex and competitive as most tourism companies are intensifying their promotional efforts aimed at tourists. Nature is the raison d'être of the tourism business and therefore the tourism organization at the national, state and local levels must make estimates about what can happen in the future, adapt to these changes and incorporate the strategic planning process into the structure of their operation (Chon \& Olsen, 1990). A sustainable tourism sector must be planned with respect for the quality of life of local people and the carrying capacity of the environment, so that tourism remains a sector with an extraordinary capacity to generate wealth in the medium and long term (Lozano et al., 2019). Otherwise, we would face saturated destinations where part of the local population would reject tourists. Therefore management policies are of great importance since they focus on preserving the environment in conjunction with local values, improving tourism productivity, competitiveness, and performance. 
To achieve good strategic management, change management, which are processes and sets of tools to help people and companies achieve the desired objectives, must be considered; it is based largely on the factor of leadership and communication skills. Change management is successful when the organization's objectives are being met through the collaboration of people and successful execution of the program itself (Baharudin et al., 2020). To maintain and be competent in a volatile environment, it is vitally important to develop change management through good leadership and communication.

The goal of implementing change is to increase the effectiveness of the organization's performance and evaluate it. Business management must have opportunities to quantitatively assess the benefits of the changes made and staff must be clear about the objectives on which to focus to develop the changes (Merzlikina \& Kozhanova, 2020). This implies new technologies and methods that adjust to business performance and market demand by taking advantage of opportunities. Staff training, programs should consider the knowledge required of staff preparing them to provide referral and support services. In addition, training must be continuous and sensitive to staff limitations, roles and responsibilities (Wetli, 2018). This training must be comprehensive in order to prepare staff who do not have complete knowledge to provide general referral assistance, and it must be sensitive to the limitations and needs of workers.

A study in Eastern Siberia states that often workers in tourism enterprises do not have elementary or basic professional education. The East Siberian State Institute of Culture mentions that at present the system of training personnel for the tourism industry must implement educational tourism programs by providing training to tourism personnel in compliance with educational standards. Tourism development is impossible without tour guides, entertainers, artisans and other specialists who contribute to the expansion of the range of culture and education, ethnocultural and environmental tourism programs and itineraries (Perova et al., 2018). It is precisely the implementation of educational tourism programs that defines the priority role of the East Siberian State Institute of Culture in training personnel for tourism, the economy and the management of hotel services in the social and cultural sphere. 
Competitiveness is the ability to innovate in order to achieve or maintain a favorable situation and compared to other companies in a number of key sectors; it has positive effects on organizational performance. One study found that performance increases when firms strengthen their competitiveness through improvements in four factors: quality, cost, delivery and flexibility (Holis et al., 2018). The ability to innovate is the most important factor in improving business performance. Sustainable competitiveness must be applied to all businesses; resource-based strategy theory points out the importance of dynamic resource capacity such as flexibility, agility, speed and adaptability to improve business performance and develop competitive advantage in organizations, with innovation being a key factor leading to this advantage (Rauf et al., 2019).

Figure 1. Factors for increasing competitiveness.

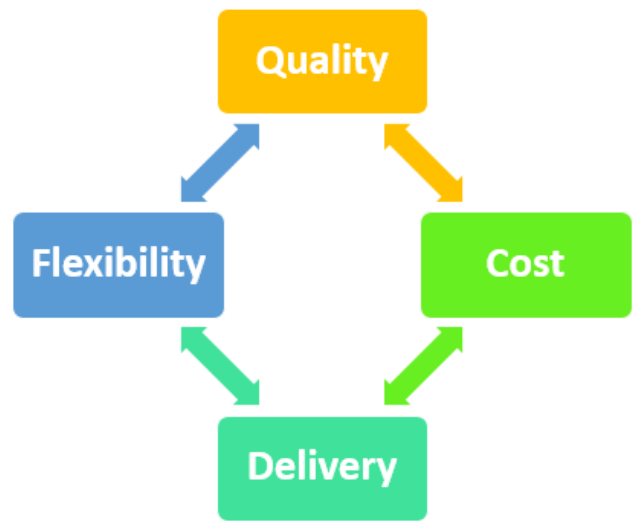

Source: (Holis et al., 2018).

Quality of service is the delivery of an excellent good or service in comparison to customer expectations; it is very important nowadays as customers are increasingly more informed due to technology and are more demanding (Idat et al., 2018). Quality of service is increasingly important and is measured from the point of view of customers, their perception of other companies and their expectations before purchasing the good or service. When an organization creates a high quality product, it can improve competitiveness and increase organizational performance both directly and indirectly (Lakhal, 2009). Quality guarantees satisfaction so that clients continue to consume the product or service offered. This is achieved by making an internal diagnosis, training staff, and continuously improving the organizational climate. 
Differentiation, the success of a company that implements differentiation is based on developing unique attributes in the product and in the performance of processes, giving a clear focus on service. In order to implement differentiating strategies in the company's value chain, the product must be of high quality, focusing on innovation, exceeding customer expectations and thus improving service (Chirinos \& Samaniego, 2016). Successful differentiation means greater process flexibility, improved product performance, optimized engineering design and improved ease of use. One way to differentiate oneself from the competition is to have products or services in the market that meet the needs of each specific client through flexible and rapid responses that offer the capacity for customization that the competition cannot match, in which technological competencies are key factors that the company must incorporate (Angel et al., 2016).

Technology management is the direction and organization of human and economic resources to create new knowledge, generate technical ideas that will enable the company to obtain new products, services and processes. It has three levels: strategic management, technological innovation and technology transfer (Tavera, 2017). Technology management creates, maintains and improves the competitive advantage in organizations from technological foundations.

\section{METHOD}

The present research study is of a descriptive-correlational type with a transversal design. It is made up of 50 managers from companies in the tourism sector in southern Lima. The sample is made up of 20 managers. As an instrument, a questionnaire was used about the independent variable strategic management model through the indicators that are: change management and personnel training, with a total of 8 questions and the dependent variable competitiveness that contains the indicators: service quality, differentiation and technological management with a total of 12 questions. The scale used is from Likert, validated by expert judgment and the questionnaire is reliable with a Cronbach's alpha coefficient of 0.823 . 


\section{RESULTS}

The questionnaire was applied to a total of 20 managers in the tourism sector in Cañete, based on which it was possible to obtain and analyze the following results:

Table 1 shows the results of the change management dimension regarding the strategic management model variable. $60 \%$ of the managers surveyed maintain that the capacity to manage change in their companies is regular, and $40 \%$ consider it to be good.

Table 1 . How do you consider the change management capacity of your company?

\begin{tabular}{|c|c|c|}
\hline Levels & Quantity & Percentage \\
\hline Very Good & 0 & $0 \%$ \\
\hline Good & 8 & $40 \%$ \\
\hline Regular & 12 & $60 \%$ \\
\hline Bad & 0 & $0 \%$ \\
\hline Deficient & 0 & $0 \%$ \\
\hline Total & 20 & $100 \%$ \\
\hline
\end{tabular}

Source: Own elaboration.

Table 2 shows the answers to the training dimension of the same variable. $55 \%$ of managers consider staff training to be regular, $40 \%$ say that the level of training is good and $5 \%$ very good.

Table 2. How do you consider the training of personnel in tourism?

\begin{tabular}{|c|c|c|}
\hline Levels & Quantity & Percentage \\
\hline Very Good & 1 & $5 \%$ \\
\hline Good & 8 & $40 \%$ \\
\hline Regular & 11 & $55 \%$ \\
\hline Bad & 0 & $0 \%$ \\
\hline Deficient & 0 & $0 \%$ \\
\hline Total & 20 & $100 \%$ \\
\hline
\end{tabular}

Source: Own elaboration.

Table 3 shows the results of the quality of service dimension of the competitiveness dependent variable. $70 \%$ say that the way to provide a better quality of service in tourism enterprises is regulated, $30 \%$ say that the way to promote the quality of service is good. 
Table 3. How do you evaluate the quality of the tourist service?

\begin{tabular}{|c|c|c|}
\hline Levels & Quantity & Percentage \\
\hline Very Good & 0 & $0 \%$ \\
\hline Good & 6 & $30 \%$ \\
\hline Regular & 14 & $70 \%$ \\
\hline Bad & 0 & $0 \%$ \\
\hline Deficient & 0 & $0 \%$ \\
\hline Total & 20 & $100 \%$ \\
\hline
\end{tabular}

Source: Own elaboration.

Table 4 expresses the results of the differentiation dimension of the competitiveness variable. $60 \%$ consider their company's differentiation strategy to be poor, $30 \%$ fair and $10 \%$ very good.

Table 4. How do you consider the differentiation strategy in your company?

\begin{tabular}{|c|c|c|}
\hline Levels & Quantity & Percentage \\
\hline Very Good & 2 & $10 \%$ \\
\hline Good & 0 & $0 \%$ \\
\hline Regular & 6 & $30 \%$ \\
\hline Bad & 12 & $60 \%$ \\
\hline Deficient & 0 & $0 \%$ \\
\hline Total & 20 & $100 \%$ \\
\hline
\end{tabular}

Source: Own elaboration.

Table 5 shows the answers to the technological management dimension of the same variable. $75 \%$ of managers consider the implementation of technological management to be poor and $25 \%$ maintain that it is regular.

Table 5. How do you consider the implementation of technology management in your company?

\begin{tabular}{|c|c|c|}
\hline Levels & Quantity & Percentage \\
\hline Very Good & 0 & $0 \%$ \\
\hline Good & 0 & $0 \%$ \\
\hline Regular & 5 & $25 \%$ \\
\hline Bad & 15 & $75 \%$ \\
\hline Deficient & 0 & $0 \%$ \\
\hline Total & 20 & $100 \%$ \\
\hline
\end{tabular}

Source: Own elaboration. 


\section{PROPOSAL}

According to the results of the survey, the following strategic management model is proposed to promote competitiveness in tourism companies that allows us to evaluate the real state of tourism companies in Cañete and then apply the model and achieve ideal results.

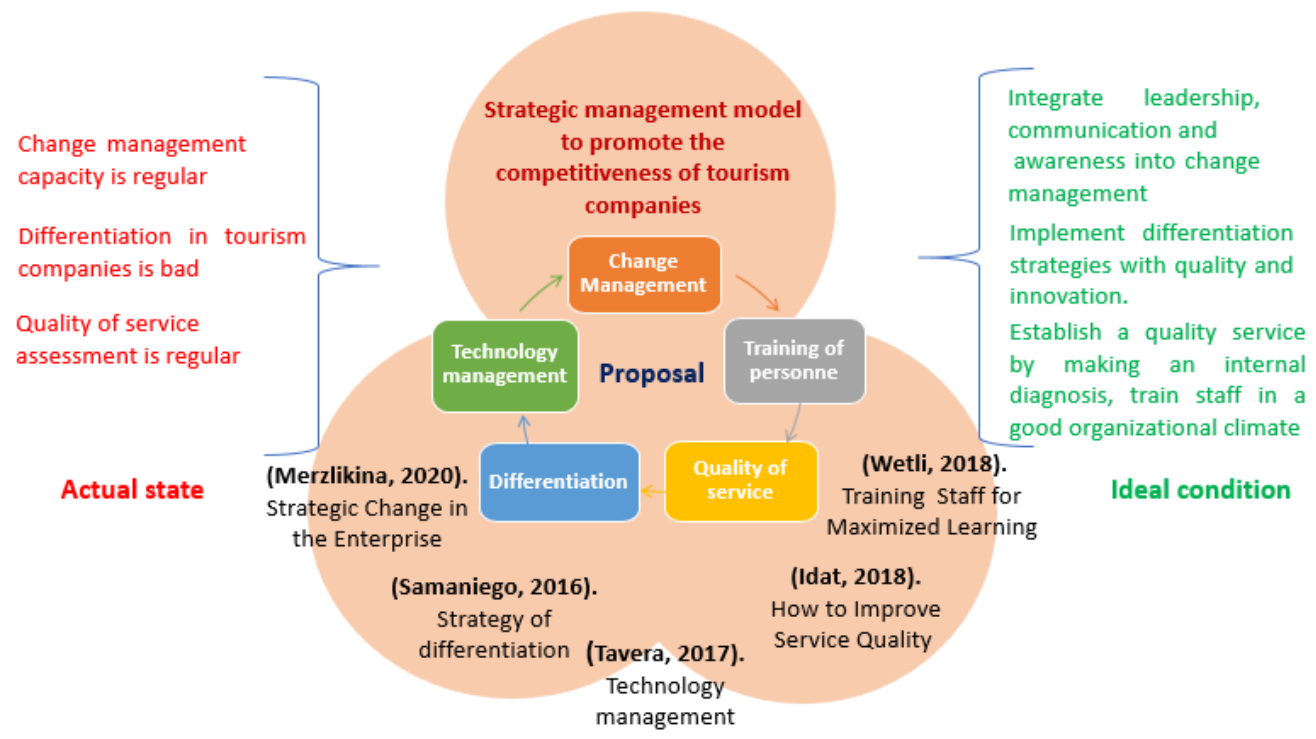

Figure 2. strategic management proposal to promote competitiveness

Source: own elaboration.

\section{DISCUSSION}

This research proposes the application of a strategic management model to improve the competitiveness of tourism enterprises.

In Table $1,60 \%$ of managers indicate that the change management capacity of their companies is regular. Therefore, for the change management capacity to be successful, the company's objective must be met, which will allow for the improvement of administrative, technical and social performance. This is in line with Baharudin et al. (2020) and Merzlikina \& Kozhanova (2020) emphasizing that change should increase the effectiveness of the company's performance, change management is of vital importance to maintain and be competent in a volatile environment; leadership, communication and awareness are essential factors in preparing the integrity of change management. 
In Table 2, 55\% indicate that training of tourism personnel is regular, so the skills, knowledge, attitudes and behaviors of your company's staff should be improved so that they can have new tools and knowledge. This is in line with Wetli (2018) and Perova et al. (2018) who consider that training should be comprehensive enough to prepare staff by providing them with general reference assistance and sensitivity to conflicting time constraints.

In Table 3,70\% consider that the quality of the tourism service should be regulated, so due to the demand of the client, strategies should be proposed to improve the quality in order to exceed their expectations. This is in line with Idat et al. (2018) and Lakhal (2009) who emphasize that an organization with a high quality product or service will be able to improve competitiveness and increase the performance of organizations both directly and indirectly, guaranteeing satisfaction so that clients continue to consume the product or service offered.

In the Table 4, 60\% express that the differentiation strategy of their company is bad, the results show that for tourism companies to implement the differentiation strategy, the value chain has to be of quality, innovative and exceed customer expectations by improving service. Chirinos \& Samaniego (2016) and Angel et al. (2016) express that the success of a business lies in differentiation by developing exceptional product attributes and performing service-focused processes, successful differentiation means greater process flexibility, improved product performance, optimized engineering design and improved ease of use.

In Table 5, 75\% of managers consider the implementation of technology management to be poor. The results indicate that tourism companies have not adopted technology to increase their competitiveness. Tavera (2017) states that technology management is the direction and organization of human and economic resources to create new knowledge, generate technical ideas that will allow the company to obtain new products, services and processes. 


\section{REFERENCES}

Angel, L. E. A. Del, Maldonado-Radillo, S. E., Martinez-Guaderrama, A. I., Angel, L. E. A. Del, Maldonado-Radillo, S. E., \& Martinez-Guaderrama, A. I. (2016). Competitive advantage from resource theory and capabilities, la ventaja competitiva, desde la teoria de recursos y capacidades. Revista Internacional Administracion \& Finanzas, 9(1), 69-80. https://econpapers.repec.org/RePEc:ibf:riafin:v:9:y:2016:i:1:p:69-80

Baharudin, I. S., Abdullah, B., Mohd Salleh, N. A., \& Shariffudin, P. (2020). A case study on change management readiness for an oil \& Gas SME Company in Malaysia. IOP Conference Series: Materials Science and Engineering, 834(1). https://doi. org/10.1088/1757-899X/834/1/012048

Chirinos-Cuadros, G. R., \& Rosado-Samaniego, J. F. (2016). Estrategia de diferenciación: el caso de las empresas industriales. Ingeniería Industrial, 034, 165. https://doi.org/10.26439/ing.ind2016.n034.1342

Ghon, K. S., \& Olsen, M. D. (1990). Applying the strategic management process in the management of tourism organizations. Tourism Management, 11(3), 206-213. https:// doi.org/10.1016/0261-5177(90)90043-9

Eliécer,J., \& Herrera, P. (2011). Gestión estratégica organizacional. https://www.ecoeediciones. com/wp-content/uploads/2017/05/Gestión-estratégica-organizacional-5taEdición.pdf

Fanyoujun. (2019). Visualization of the Frontier Evolution of Strategic Management Based on Knowledge Map. Fournal of Physics: Conference Series, 1314(1). https://doi. org/10.1088/1742-6596/1314/1/012136

Gimbert, X. (2010). Pensar estratégicamente: Modelos, conceptos y reflexiones MANAGEMENT.

Holis, Y. M., Syabri, I., \& Prabatmojo, H. (2018). An Examination of Regional Competitiveness: Early Findings from Banten, Indonesia. IOP Conference Series: Earth and Environmental Science, 158(1). https://doi.org/10.1088/1755-1315/158/1/012050 
Idat, M., Gina, A. S., \& Ardi, M. N. (2018). How to Improve Service Quality in School Counselling Services? IOP Conference Series: Materials Science and Engineering, 288(1). https://doi.org/10.1088/1757-899X/288/1/012083

Lakhal, L. (2009). Impact of quality on competitive advantage and organizational performance. Fournal of the Operational Research Society, 60(5), 637-645. https://doi. org/10.1057/palgrave.jors. 2602601

Lozano-Oyola, M., Blancas, F. J., González, M., \& Gaballero, R. (2019). Sustainable tourism tags to reward destination management. Fournal of Environmental Management, 250, 109458. https://doi.org/10.1016/j.jenvman.2019.109458

Merzlikina, G. S., \& Kozhanova, T. E. (2020). Strategic Change in the Enterprise: Foresight and Management. IOP Conference Series: Earth and Environmental Science, 459(6). https://doi.org/10.1088/1755-1315/459/6/062059

Perova, E. Y., Budaeva, S. B., \& Kondrashova, E. V. (2018). From the Experience of Staff Training for Tourism Industry (A Case of the East Siberian State Institute of Culture). IOP Conference Series: Earth and Environmental Science, 204(1). https://doi. org/10.1088/1755-1315/204/1/012037

Quintana, L. (2019). Gestión del Destino Turístico y su Planificación Estratégica. Gestiopolis. https://www.gestiopolis.com/gestion-del-destino-turistico-y-su-planificacionestrategica/

Rauf, A., Kadir, A. R., \& Kamariah, N. (2019). The Role of Firm's Unique Resource in Developing Sustainable Competitive Advantage from Strategy Inimitability and its Effect on Firm Performance of Mining Companies in Indonesia. Fournal of Physics: Conference Series, 1341(9), 092022. https://doi.org/10.1088/17426596/1341/9/092022

Stratec. (2019). La importancia de la Gestión Estratégica en las empresas. https://www. stratecsoluciones.com/blog/la-importancia-de-la-gestion-estrategica-en-lasempresas/ 
Tavera, J. (2017). La gestión de la innovación tecnológica en las empresas. Pensamiento Crítico, 21(2), 145. https://doi.org/10.15381/pc.v21i2.13266

Wetli, A. (2018). Training Temporary Reference Staff for Maximized Learning: A Case Study. Fournal of Academic Librarianship, 45(5), 102032. https://doi.org/10.1016/j. acalib.2019.04.009 
